University of Nebraska - Lincoln

DigitalCommons@University of Nebraska-Lincoln

Faculty Publications: Agricultural Economics

Agricultural Economics Department

2001

Slotting Allowances and Price-Cost Margins: A Note

Azzeddine Azzam

Aazzam1@unl.edu

Follow this and additional works at: https://digitalcommons.unl.edu/ageconfacpub

Part of the Agricultural and Resource Economics Commons

Azzam, Azzeddine, "Slotting Allowances and Price-Cost Margins: A Note" (2001). Faculty Publications: Agricultural Economics. 77.

https://digitalcommons.unl.edu/ageconfacpub/77

This Article is brought to you for free and open access by the Agricultural Economics Department at DigitalCommons@University of Nebraska - Lincoln. It has been accepted for inclusion in Faculty Publications: Agricultural Economics by an authorized administrator of DigitalCommons@University of Nebraska - Lincoln. 
Published in Agribusiness 17:3 (2001), pp. 417-422. Copyright (C 2001 John Wiley \& Sons, Inc. Used by permission. http://www3.interscience.wiley.com/journal/35917/home

This paper was motivated by the discussion at the workshop "Structural Change and Competitiveness in Product Industry: Methodology and Data Requirements," which was organized on February 19, 1999, by the USDA Economic Research Service, Washington, DC. The author is grateful to an anonymous reviewer for Agribusiness for helpful guidance in revising the paper; the usual disclaimer applies. This is University of Nebraska Agricultural Research Division Journal Series No. 13067.

\title{
Slotting Allowances and Price-Cost Margins:
}

\section{A Note}

\author{
Azzeddine M. Azzam
}

Department of Agricultural Economics, 103 Filley Hall, University of Nebraska-Lincoln, Lincoln, NE 68583-0922; email aazzam1@unl.edu

\begin{abstract}
It has become common practice for retail grocers to charge grocery manufacturers a slotting allowance for placing products on the retail shelf. Manufacturers view the allowance as anti-competitive. Retailers view it as compensation for the risks associated with stocking new products. The largely theoretical literature on the subject is consistent with both views. This article proposes an empirical model to test the effect of slotting allowances on performance, and discusses if and how the model can be tied to the qualitative predictions of existing theoretical literature.
\end{abstract}

\section{Introduction}

Since the mid-1980s, it has become common practice for grocers to charge grocery manufacturers a slotting allowance for placing products on the retail shelf. ${ }^{1}$ Estimates of annual expenditures on slotting allowances range from 6 to 9 billion US dollars, accounting for about half of product promotion expenditures by manufacturers (Kelly, 1991). As a proportion of product introduction costs, slotting allowances represent $16 \%$, almost the same percentage spent on R\&D and market research (Lariviere \& Parmanabhan, 1997). The amount charged per new product is negotiated on an individual basis and may range from a few thousand to a million dollars, depending on the product, the size of the manufacturer, the size of the retail chain, and whether the chain is regional or national (Pyle, 1995).

To manufacturers, the allowances represent evidence of retailer market power. ${ }^{2}$ Smaller manufacturers, in particular, consider them as a surrogate for re-

1 Slotting allowances are charges for new as well as existing products. Slotting allowances for existing products include "failure fees," "pay to stay fees," and "free fills" (Pyle, 1985).

2 Recently, fresh product wholesalers have asked the Secretary of Agriculture to look into the implications of slotting allowances and other trade practices for competition in the marketing chain. In response, a workshop entitled "Structural Change and Competitiveness in Product Industry: Methodology and Data Requirements" was held in Washington, D.C., on February 19, 1999, to discuss alternative empirical methodologies for studying the competitive effects of slotting allowances. 
tailer price discrimination in favor of their larger rivals, and as a cost-raising strategy by larger manufacturers to "muscle out" the smaller ones (Kelly, 1991). To retailers, the allowances are compensation for the risks associated with adding new products to inventory. The verdict from economists is correspondingly mixed. To some, the allowances serve the purpose of dampening competition (Shaffer, 1991). To others, they serve as an instrument of risk-sharing (Sullivan, 1997), signaling/screening (Chu, 1992), and signaling (Lariviere \& Parmanabhan, 1997) in an uncertain retail environment.

Shaffer's (1991) analysis shows that it is more profitable for retailers to extract a fixed slotting allowance and pay a higher manufacturer price than to charge no allowance and pay a lower manufacturer price. In the model, perfectly competitive manufacturers offer retailers a two-part tariff contract (the wholesale price plus a [negative] slotting allowance) and must break even. A retailer accepts a contract that maximizes its own profits, given the contracts bought by rivals who must also earn non-negative profits. In equilibrium, manufacturers charge a higher wholesale price to retailers, and retailers charge a fixed allowance to compensate for lost revenues. A higher wholesale price will induce rivals to charge a higher retail price. So, in equilibrium, both the wholesale price and the retail price increase.

To demonstrate the risk-sharing role of allowances, Sullivan (1997) assumes consumer demand is a function of the full price of the product, which includes the money price plus consumer search costs. The latter decrease as the number of retail products increases. Retailer costs are a function of quantity sold and new products. Manufacturer supply of new products depends on the costs of product development and production. A rightward shift in the supply of products due, for example, to lower development cost increases the number of products, raises retail costs, and lowers consumer search costs. Lower search costs translate into a higher money price for the quantity sold. If the increase in the retail margin does not cover the increase in retail costs, the retailer will charge a slotting or risk-sharing allowance. Observed trends in prices and margins, Sullivan argues, are consistent with the supply-demand model hypothesis, and are indicative of competitive conduct in retailing and manufacturing.

The premise of Chu's (1992) paper is that introduction of new products raises the problem of asymmetric information: manufacturers with "high demand" products ("high types"), and manufacturers with "low demand" products ("low types"), are more informed about their respective products than retailers. Chu examines two scenarios to deal with information asymmetry. In the first scenario, the high types move first and signal their confidence in their products through advertising. In the second, retailers move first and use slotting allowances to screen the high types from the low types. In the signaling case, both types "overadvertise" and "overprice" relative to the perfect information equilibrium. However, the high types may succeed in differentiating themselves from low types when product failure has been historically high. In the screening case, only the high types will accept a retailer's offer of a slotting allowance, prices do not increase relative to their complete information level, and retailers expropriate the channel surplus.

Lariviere and Parmanabhan (1997) also consider asymmetric information. This time, however, the manufacturer moves first; i.e., offer the allowance to the retailer. The purpose of the allowance is twofold: to signal information about product demand and recompense the retailer for the cost of stocking the product. De- 
mand for the product responds to retail price as well as retailer merchandising effort. The prediction of Lariviere and Parmanabhan's model is that the optimal contract is a slotting allowance and a lower wholesale price to induce retailer merchandising effort. Retailers who accept the allowance only break even. So, one should find, as Lariviere and Parmanabhan did, the average net revenue per unit of shelf space to be higher for slotted than unslotted products. However, Lariviere and Parmanabhan do not dismiss the possibility of retailer power in dictating slotting allowances.

Granted that slotting allowances can be rationalized on several grounds, the qualitative predictions of the various models remain largely untested. Understandably, absence of slotting fee data may limit the scope of meaningful empirical work. But should data become available, it is not clear how one should proceed in discriminating among the competing hypotheses in the literature. A reducedform approach is easy to implement but does not guarantee that the empirical results conform to the underlying model. Structural models are more appropriate but, because of nonlinearities, are not easy to implement without overstripping simplifications. In this article, I propose one empirically implementable model for testing the anti-competitive effects of slotting allowances. Specifically, I use a fairly conventional oligopoly model and demonstrate how slotting allowances can be introduced into a price-cost margin equation in a manner similar to introducing contracts for intermediate input (Lukacs, 1997). I also discuss how the parameters of the model may relate to the qualitative predictions in the literature.

\section{The Model}

Denote by $q_{i j}$ the quantity of a product sold by the $i$ th retailer in the $j$ th retailing region, such that $Q_{j}=\sum_{i=1}^{N_{j}} q_{i j}$ is total quantity sold, and $N_{j}$ is the number of retailers in the $j$ th region. Regional retail demand is represented by the inverse demand function $P_{j}\left(Q_{j}\right)$ where $P$ is the retail price. Suppose for the moment that, instead of charging a manufacturer the usual lump-sum payment, the retailer imposes a per-unit slotting allowance $A_{i j}$. The manufacturer supplies the product nationally at wholesale price $w$. Assuming the relationship between the retail and wholesale product is of fixed proportions, retailer profits are:

$$
\pi_{i j}=P_{j}\left(Q_{j}\right) q_{i j}-\left(w(Q)-A_{i j}\right) q_{i j}-c_{i j} q_{i j},
$$

where $Q$ is the total (national) supply of the product, and $c_{i j}$ is (constant) marginal cost. The per-unit slotting fee could be viewed either as a negotiated reduction from the manufacturer price, or a per-unit rental charge for shelf space. In the latter case, the retailer sells the product and the shelf space to stock it.

Differentiation of (1) with respect to $q_{i j}$ yields the first order condition

$$
P_{j}+A_{i j}-w-c_{i j}=-q_{i j} \frac{d P_{j}}{d Q_{j}} \frac{\partial Q_{j}}{\partial q_{i j}}++q_{i j} \frac{d w}{d Q} \frac{\partial Q}{\partial q_{i j}},
$$

which can be rewritten as

$$
\frac{\pi_{i j}}{P_{j} q_{i j}}=\beta_{1} \frac{S_{i j}^{r}}{\eta_{j}}+\beta_{2} \frac{S_{i j}^{n}}{\epsilon_{j}} R_{i j}
$$


where, for the $i$ th retailer in the $j$ th region,

$$
\begin{gathered}
\frac{\pi_{i j}}{P_{j} q_{i j}}=\text { the empirical measure of the price-cost margin, } \\
\beta_{1}=1+\lambda_{i j} \text {, where } \lambda_{i j} \text { is the } i \text { th retailer's conjectural variation in the } j \text { th re- } \\
\text { gional retail market, } \\
\beta_{2}=1+\theta_{i j}, \text { where } \theta_{i j} \text { is the } i \text { th retailer's conjectural variation in the } j \text { th na- } \\
\text { tional wholesale market, } \\
-\frac{S_{i j}^{r}}{\eta_{j}}=\text { the ratio of retailer's market share in the regional retail product market } \\
\text { to the regional elasticity of demand. } \\
-\frac{S_{i j}^{n}}{\epsilon}=\text { the ratio of retailer's market share in the national wholesale market to } \\
\text { the national elasticity of wholesale supply, and }
\end{gathered}
$$

The superscripts $r$ and $n$ stand for national and regional, respectively.

In practice, retailers negotiate a fixed rather than a per-unit slotting allowance. ${ }^{3}$ This implies that the additional revenue $A_{i j} q_{i j}$ on the left hand side of equation (3) is a lump-sum amount, and hence, does not vary with $q_{i j}$. In that case, profit maximization results in the price-cost margin equation

$$
\frac{P_{j} q_{i j}-w q_{i j}-c_{i j} q_{i j}}{P_{j} q_{i j}}=\beta_{1} \frac{S_{i j}^{r}}{\eta_{j}}+\beta_{2} \frac{S_{i j}^{n}}{\epsilon} R_{i j} .
$$

Note, however, that if the ratio of revenue from the slotting allowance to sales is added to both sides of (4), i.e.

$$
\frac{\pi_{i j}}{P_{j} q_{i j}}=\beta_{1} S_{i j}^{r}+\beta_{2} S_{i j}^{n} R_{i j}+\beta_{3} \frac{A_{i j} q_{i j}}{P_{j} q_{i j}}
$$

one obtains the same expression for the price-cost margin in (3), plus the additional ratio on the right hand side with the coefficient $\beta_{3}{ }^{4}$

What equation (5) reveals is that the empirical specification of the price-cost margin of a retailer charging slotting allowances should include the retailer's regional share and national share, elasticities of demand and supply, and the proportion of revenue accounted for by slotting allowances. The familiar measure of oligopolistic (oligopsonistic) conduct is captured by $\beta_{1}\left(\beta_{2}\right)$. Interpretation of the effect of slotting allowances on performance, as measured by $\beta_{3}$, is not as straightforward and merits some discussion. The simplest case is when $\beta_{3}=1$. Performance then is the same in the presence or absence of slotting allowances. The more interesting case if when $\beta_{3}$ takes values other than 1 . Abstracting for now from oligopsony power, if one finds no evidence of oligopoly power, but finds that $\beta_{3}=0$ rather than 1 , then the retailer is making a normal profit in equilib-

3 This is also consistent with the specification of slotting allowances in the theoretical literature.

4 Note that since $q_{i j}$ is a decision variable, its optimizing level from (3) would not coincide with that from equation (5). This implies that the level of $A_{i j}$ would not be the same in the two equations either and, in the lump-sum case, it would be equivalent to the lump-sum allowance divided by the quantity sold. 
rium. This would be consistent with Lariviere and Parmanabhan's (1997) signaling model, Chu's (1992) screening model, and Sullivan's (1997) risk-sharing model. Recall that, in the first, the optimal contract is a slotting allowance to cover retailer stocking costs and a lower wholesale price to induce retailer merchandising effort. In the second, high type manufacturers pay the allowance to differentiate themselves from the low types. In both cases, retailers simply break even. In the third, slotting allowances equate the demand and supply of new products with no presumption that retailers have more bargaining power with manufacturers or vice-versa. Note that evidence of retail oligopoly power in combination with $\beta_{3}=0$ would still be consistent with the signaling/screening, since retailers still price over marginal cost in both cases. It would not, however, be consistent with Sullivan's risk-sharing story, where both manufacturers and retailers are price takers.

Evidence of market power in the presence of slotting allowances would, with some qualifications, also be consistent with Shaffer's (1991) predictions. His model predicts an increase in the wholesale price, retail price, and retailer rents. The source of increased rent, in the presence of slotting allowances, is not oligopsony power but the increase in the retail price above its Nash equilibrium level. Since the econometric model in this paper is a conjectural oligopoly model of homogeneous quantity-setting retailers, rather than differentiated retailers who play Nash in prices, it would be quite a stretch to infer pricing above the Nash equilibrium level from the estimate of $\beta_{1}$. However, failure to reject competitive retailer conduct in the presence of slotting allowances would not be supportive of Shaffer's predictions.

Turning now to oligopsony power, recall that none of the models in the literature presumed that power on the part of retailers, or any bargaining power for that matter. By oligopsony power, I mean retailer ability to lower wholesale prices by restricting purchases relative to their competitive level. This is captured by the coefficient $\beta_{2}$. By retailer bargaining power, I mean retailer ability to depress prices without any reduction in quantity. As explained in Blair and Harrison (1993), this is equivalent to buyers imposing an all-or-none decision on the sellers. The supply curve of sellers, in this case, is the all-or-none supply curve which lies below the traditional supply curve (pp. 73-74). This, I suggest, is captured by the coefficient $\beta_{3}$. Hence it is plausible to find no evidence of oligopsony power $\left(\beta_{2}=0\right)$, or find evidence of both. In other words, an up-front payment, like a slotting allowance, to distribute a product can be "dictated" by a retailer with or without restricting purchases to obtain a lower wholesale price.

Admittedly, since the empirical model in this article does not conform directly to the various theoretical models underlying the predictions, its link with those predictions is rather "loose." In that sense, the model is a reduced-form "workhorse" which can either be used to provide indirect evidence of the competing hypotheses in the literature or used as a stand-alone structure-performance model with slotting allowances. ${ }^{5}$ The ideal model, of course, would be a structural model that is complex enough to nest all the competing hypotheses, and simple enough to estimate its parameters. I leave construction of such model for future research.

5 Estimating the model would require a panel data set of retailers over several regions. 


\section{Concluding Remarks}

In recent years, it has become common practice for retail grocers to charge grocery manufacturers a slotting allowance for placing products on the retail shelf. Some manufacturers allege the allowance is anti-competitive. The largely theoretical literature suggests that the allowance can be pro- or anti-competitive. This article proposes a methodology for testing the relationship between slotting allowances and price-cost margins and discusses how it can be tied to the qualitative predictions of existing theoretical literature.

\section{References}

Blair, R. D., \& Harrison, J. L. (1993). Monopsony: Antitrust law and economics. Princeton, NJ: Princeton University Press.

Chu, W. (1992). Demand signaling and screening in channels of distribution. Marketing Science, 11, 327-347.

Kelly, K. (1991). The antitrust analysis of grocery slotting allowances: The pro-competitive case. Journal of Public Policy and Marketing, 10, 187-198.

Lariviere, M. A., \& Parmanabhan, V. (1997). Slotting allowances and new product introductions. Marketing Science, 16, 122-128.

Lukacs, P. (1997). Input contracts, market structure and the empirical specification of price-cost margins. Economic Letters, 55, 139-143.

Pyle, R. R. (1995). Statement before the Federal Trade Commission Slotting Fees Hearings, November 8, 1995. Available online: http://www.flc.gov/opp/global/slott.htm.

Shaffer, G. (1991). Slotting allowances and resale price maintenance: A comparison of facilitating practices. Rand Journal of Economics, 22, 120-135.

Sullivan, M. W. (1997). Slotting allowances and the market for new products. Journal of Law and Economics, XL, 461- 493.

Azzeddine M. Azzam is a professor of Agricultural Economics at the University of Nebraska-Lincoln. He earned his PhD in 1984 from the University of Nebraska-Lincoln. His current research interest is empirical analysis of market structures and organization in the food marketing chain. 